\title{
Perceptions of Entrepreneurial Behaviour in Botswana
}

\author{
Rina Makgosa, PhD \\ Senior Lecturer, Marketing, \\ University of Botswana, Faculty of Business, \\ Department of Marketing, Private Bag UB 00701. \\ Gaborone, \\ Botswana;
}

Phone: 00267355 4060;

Fax: 00267318 5102;

Email:makgosa@mopipi.ub.bw.

\author{
Henry Ongori, MBA (Corresponding Author) \\ Senior Lecturer, Management, \\ University of Botswana, \\ Faculty of Business, \\ Department of Management, \\ Private Bag UB 00701. \\ Gaborone, \\ Botswana; \\ Phone: 00267355 5109; \\ Fax: 00267318 5102; \\ Email: ongorih@ mopipi.ub.bw.
}

\author{
Accepted: April 25, 2012 Published: June 02, 2012 \\ Doi:10.5296/ijld.v2i3.1885 URL: http://dx.doi.org/10.5296/ijld.v2i3.1885
}

\begin{abstract}
With the high rate of unemployment in Botswana, it has become imperative that the alternative source of employment seen by policy makers and researchers as the panacea to the problem, is entrepreneurship. Although, research has been conducted on entrepreneurship, little has been done on the university students' perceptions of entrepreneurial behaviour in Botswana. To fill this gap, this paper seeks to investigate university students' perceptions of various entrepreneurial characteristics, motivators and challenges in Botswana. To achieve this, a sample of 394 undergraduate students of the University of Botswana was targeted. Findings of the current study indicate that students perceived an entrepreneur as an individual who possesses the right managerial skills, take risks, contribute to the economy, utilize available resources optimally, is creative and successful. Although the current study is based on undergraduate students, an investigation of entrepreneurial behaviour that exists among potential entrepreneurs in Botswana is important, since it will enable policy makers and other stakeholders to intensify and channel initiatives to promote self employment.
\end{abstract}


Key words: Botswana, Entrepreneur, Entrepreneurship, Motivators, Traits

\section{Introduction}

Entrepreneurship has been perceived as an important research field by scholars and policy makers alike for some time. As noted by other scholars (Mambula and Sawyer, 2004; Segal, Borgia and Schoenfeld, 2005; Thurik and Wennekers, 2004), the term 'entrepreneurship' has dominated speeches delivered from almost every public platform, media and publication today. The developing interest in entrepreneurship has been prompted by the fact that policy makers are confronted by increasing challenges of globalization, unemployment, job creation, economic growth and being competitiveness in the global market (Henry, Hill and Leitch, 2006). The spread of entrepreneurial activity is a critical element of economic development, competitive power, social and political stability (Thurik and Wennekers, 2004). In particular, entrepreneurship plays a fundamental role in the creation of new businesses, new jobs, reduction in unemployment, generation of new technologies, introduction of new product and market innovations and efficient utilization of resources (Postigo, Iacobucci and Tamborine, 2003; Thompson, 1999).

Entrepreneurs continue to revitalize both developed and developing economies. For instance, entrepreneurship was considered to be America's secret weapon for success and the main contributor to the country's superior position in the global economy (Timmons, 1994 in Pretorius, Nieman and Vuuren, 2005). As noted by Thurik and Wennekers, (2004) much of the excess growth of the Unites States as compared to European countries is due to fact that the country has been much quicker to absorb the virtues of entrepreneurship. Although the level of entrepreneurial activity varies across countries, developing countries like Botswana have shown keenness on the benefits of accelerated entrepreneurship. In Botswana, the National Development Plan 9 (2003) asserts the country's long term goal of contributing towards entrepreneurship skills development. To meet the strategic priority of developing and intensifying entrepreneurial activity, several initiatives have been implemented (Bonu, 1999; National Development Plan 9, 2003). Also, recently initiatives such as Citizen Entrepreneurial Development Agency (CEDA) and Local Enterprises Authority (LEA) have been set up in an attempt to promote entrepreneurial activities in Botswana. Similarly, the University of Botswana and other local tertiary institutions offer courses on entrepreneurship in their business administration curriculum.

Despite the increasing interest on entrepreneurial activity in both developed and developing economies, it has not reached a desired national level in Botswana (Mgaya and Magembe 2007; Ronan, Chinyoka, Iwisi and Moeti, 1997). Previous research on entrepreneurship has also largely concentrated on the developed nations such as Europe (Galloway, Kelly and Keogh, 2006; Gurol and Atsan, 2006; Johnson, 2001; Thurik and Wennekers, 2004) and North America (Segal et al., 2005). Little empirical research has come from developing countries in Africa (Mambula and Sawyer, 2004) and especially Botswana (Mgaya and Magembe, 2007; Ronan et al., 1997). Therefore, the current study seeks to address these gaps by exploring entrepreneurial behaviour in Botswana. Specifically, this paper investigates university students' perceptions of key characteristics that entrepreneurs need to possess, their motivators and challenges. 


\section{Literature review}

Entrepreneurship Defined

Many definitions of entrepreneurship have been proposed in the available literature and a universally agreed upon definition does not exist. Some scholars define entrepreneurship as a process of creating something new. In particular, entrepreneurship has been defined as the process through which individuals and/or teams create value by bringing together unique packages of resources or inputs to exploit opportunities in the environment (Pretorius et al., 2005). Henry et al., (2005) also defined entrepreneurship as a process of creating something different - a new economic entity centred on a novel product or service or at the very least one which differs significantly from products or services offered elsewhere in the market. Other researchers emphasize that entrepreneurship is a process of creating and seizing an opportunity with the available resources. For instance, entrepreneurship has been defined as an act which involves creativity and the creation is based on perceiving an opportunity, risks and the end results of the process is to add value to the individual, community and society at large (Segal et al., 2005). Entrepreneurship has been also defined as managerial behaviour, which consistently exploits opportunities beyond ones' capabilities (Thompson, 1999). Likewise, Collins, Smith, and Hannon, (2006) consented that entrepreneurship is way of thinking that is opportunity based and holistic in approach.

\section{Entrepreneurial Behaviour in General}

Definitions of an entrepreneur are central to the understanding of entrepreneurial behaviour since they specify several key attributes of entrepreneurs and the activities they undertake. For example, an entrepreneur is defined as an individual who takes agency and initiative, who assumes responsibility, ownership of making things happen, able to create novelty, manages risks attached to the processes. In addition, he has the persistence to see things through different perspective, even when faced with obstacles and difficulties (Johnson, 2001). Being an entrepreneur is also one who is self employed and who starts, organizes, manages, and assumes responsibility for a business, offers a personal challenge that many individuals prefer over being an employee working for someone else (Segal et al., 2005). Recognizing that the attributes of entrepreneurs are not exhaustive, Themba, Chamme, Phambuka and Makgosa (1999) noted that an entrepreneur is an individual who possesses initiative, self confidence, moderate risk propensity, individuality, innovativeness and creativity.

The literature also abounds with research that has investigated on who is entrepreneur and what he or she does. However, research has suggested that various entrepreneurial characteristics are based on a number of theoretical perspectives. For detailed discussions of the perspectives of entrepreneurship see, Day, Reynolds, and Lancaster, 2006; Ratashobya, 1999; Robertson, Collins, Medeira and Slater, 2003. Most of the previous studies rely upon the trait theory. The trait theory focuses on personality traits, which drive an individual's decision to become an entrepreneur (Robertson et al., 2003); or identifies common links or motivations among entrepreneurs that bind them together (Henderson and Robertson, 1999). As also noted by Day et al., (2006), this theory is concerned with what the entrepreneur does rather than what they are. 
Following this theory, researchers have recommended unique personality traits of entrepreneurs. In particular, in a study by Henderson and Robertson (1999) innovation, hard working, self belief, determination was the mostly cited personality traits in the United Kingdom. In fact, mature graduate students stressed self confidence, selfishness, innovation and strong character while undergraduate students emphasized innovation and ambition as key personality traits. Students in both Argentina and Italy also agreed that entrepreneurs are skilful, dynamic, risk takers, and possess good entrepreneurial vision (Postigo et al., 2003). Additionally, risk taking, leadership, motivation, ability to resolve crises, creativity, low level of risk aversion and decision making ability have been identified as critical traits of entrepreneurs (Pretorius et al., 2005). Similarly, Gurol and Atsan (2006) stressed that need for achievement, locus of control, risk taking propensity, tolerance for ambiguity, innovativeness, and self confidence are significant in the understanding of entrepreneurial behaviour. Other studies (Johnson, 2001; Thompson, 1999) provided a more comprehensive view of the key entrepreneurial characteristics: motivation, taking ownership, being accountable, making independent and self directed decisions, being open to new practices, ideas and information, being tolerate to ambiguity and uncertainty, creativity, flexibility, problem solving, decision making, ability to see and capture opportunity, awareness of risks and capacity to manage, persistence, and capacity to make an impact.

Rather than focusing on the entrepreneurial personality traits, other researchers have adopted the social developmental approach in the study of entrepreneurial characteristics. This approach concentrates on the personal and social factors that differentiate entrepreneurs from others such as gender, education, family background, stage of career, work experience, and early life experiences (Gurol and Atsan, 2006; Henderson and Robertson, 1999). Consequently, entrepreneurs have being characterized as being male, married, belonging to a specific ethnic minority group, and those who have shown entrepreneurial behaviour from childhood (Day et al., 2006; Gurol and Atsan, 2006). According to Day et al., (2006) this approach is about who is an entrepreneur rather than what entrepreneurs do.

Using the competencies approach, the literature also demonstrated that entrepreneurs possess certain skills or abilities that enable them to become more readily adaptive to change, develop their creativity, or can be used in decision making. For example, according to Henry et al., (2005) an entrepreneur possesses the following skills: technical skills which includes written and oral communication; business management skills which is about planning, decision making, marketing and accounting skills and personal entrepreneurial skills which is concerned with inner control, innovation, and risk taking. Negotiation, salesmanship, leadership, creative thinking, management of technological innovation, new product marketing, confidence, skills in competitive strategy, identifying market opportunities, financial acumen, organisational skills and problem solving abilities have been associated with entrepreneurial behaviour (Thurik and Wennekers, 2004). In addition, Mambula and Sawyer, (2004) argued that an entrepreneur should have skills of inner control, planning and goal setting, risk taking, innovation, reality perceptions, use of feedback, decision making, human relations and independence. Similarly, entrepreneurs should have the ability to be innovative, knowledge of how the market functions, manufacturing know how, marketing skills, business management skills and the ability to cooperate (Littunen, 2000). 
Another approach to the study of entrepreneurial behaviour is to look at the role of an entrepreneur in economic terms. Drawing from this perspective, an entrepreneur is perceived as an engine for economic development through the ability to create new job opportunities, exploitation of opportunities, generation of new technologies, introduction of new products and efficient utilization of resources (Gurol and Atsan, 2006; Postigo et al., 2003).

Other studies have described entrepreneurial behaviour by looking at the external factors that drive or discourage individuals to venture into entrepreneurship. There are two broad categories of external motivational factors which influence one to venture to entrepreneurship namely pull and push factors (Segal et al., 2005). The "pull" forces are positive external factors that attract individuals to pursue entrepreneurial activities such as seeking independence, self fulfilment, wealth creation, availability of resources, quality of life, tax reduction, social upheaval, supportive social and economic culture and other desirable outcomes. "Push" forces are negative external forces that drive individuals to pursue entrepreneurial activities such as difficulty in finding employment, recession and frustration with the previous employment. Frustrations with the previous employment include job dissatisfaction, insufficient salary, inflexible work schedule, redundancy and blocked promotion. Research has shown that the pull factors are more instrumental than push factors as drivers of entrepreneurial behaviour. For instance, students in Argentina and Italy (Postigo et al., 2005) provided the following as reasons why someone starts a new venture: putting ones' idea into practice, personal independence, creating something new, to be head of an organization, economic independence, to accumulate a personal future and to earn more than an employee. Too much risk, lack of initial funding, too much competition, doubt about entrepreneurial skills, bad prospect after retirement, lack of marketing strategy and fear of failure were identified as the key challenges of starting a new business.

Although available research into entrepreneurial characteristics have been conducted, there is still formidable problems in conceptualizing and operationalizing the concept of entrepreneurship and a wealth of data available lacks consistency in terms of purpose (Day et al., 2006). Research dealing with entrepreneurship has also been criticized for being in its infancy, focusing on conceptual and methodological debates and that it is conducted in an ad hoc basis (Henry et al., 2005. Additionally, research has generated mixed findings (Segal et al., 2005) and owing to the varied approaches to the study of entrepreneurship no single attribute has been found to exclusively describe entrepreneurship (Henderson and Robertson, 1999).

\section{Entrepreneurial Behaviour in Botswana}

Since independence in 1966, Botswana has experienced the fastest growth in the world owing to stockpiling of foreign exchange reserves and revenues generated from diamond mining (Botswana Review, 2007-2008; National Development Plan 9, 2003). Despite the rapid growth in Gross Domestic Product (GDP) over the past decades, unemployment and the need to diversify the economy away from diamonds remain the principal challenges facing Botswana. The general belief among policy makers and scholars alike is that increased entrepreneurial activity will make a significant contribution to the country's economic development. Consequently, a number of programmes aimed at encouraging entrepreneurial 
activity have been implemented (Bonu, 1999; National Development Plan 9 2003-2009; Mgaya and Magembe 2007).

From the academic view-point, aspects of entrepreneurship that have been studied in Botswana range from the investigations of the level of entrepreneurship (Ronan et al., 1997), key motivations of entrepreneurship (Mgaya and Magembe 2007), to discussions of the role of culture (Themba et al., 1999) and government policies (Bonu, 1999) on entrepreneurship skill development. In particular, a study on motivations of entrepreneurship in Botswana found that university students could be encouraged into entrepreneurial activity by the strong desire to start a business, more government support, the desire to be famous, self belief and income stability (Mgaya and Magembe 2007). A low level of entrepreneurship was also found in Botswana. In fact, small business entrepreneurs were found to be performing badly in a number of personality characteristics, business skills and attitudinal traits (Ronan et al., 1997).

Despite the amount of attention accorded to a wide range of issues relating to entrepreneurship in Botswana, research is still lacking. For instance, some studies relied on desk research without empirical evidence (Bonu, 1999; Themba et al., 1997). The empirical studies focused on different target groups such as experts that offered financial assistance to entrepreneurs (Ronan et al., 1997) and university students (Mgaya and Magembe 2007), which offer varied views about entrepreneurial behaviour in Botswana. Therefore, in the current study entrepreneurship has been conceptualized as comprising of several broad categories of entrepreneurial characteristics that have been proposed in the literature-personality, skills, personal factors and economic role.

\section{Methodology}

Data for this current study was mainly collected through a survey research design in a form of a questionnaire. The use of a questionnaire is common in the entrepreneurship literature (Garol and Atsan, 2006; Littunen, 2000; Mambula and Sawyer, 2004). The questionnaire was divided into three sections. The first section comprised 29 items, which measured the key dimensions of entrepreneurial behaviour. Items were selected because they were frequently proposed as key characteristics of entrepreneurship in several past studies (Garol and Atsan, 2006; Littunen 2000; Postigo et al., 2003). The second section included questions about personal factors that influence perceptions of entrepreneurship mainly gender and age. The final section entailed open ended questions about reasons which could influence university students to venture into entrepreneurship and challenges that they could face as entrepreneurs.

The questionnaire was administered by the authors in a classroom setting to third and fourth year university students. Third and fourth year students from the Faculty of Business were considered as an ideal target group in this study, because they have studied entrepreneurship in the business curriculum and are about to join other job seekers in an economy with a high level of unemployment. Similarly, students constitute a significant proportion of potential entrepreneurs in both developed and developing nations (Postigo et al., 2003). 


\section{Al Macrothink}

\section{Data Analysis and Findings}

\section{Profile of the Sample}

Four hundred students were targeted and 6 questionnaires were discarded because of too many missing data. The final sample comprised 394 students. Of those who responded, $61 \%$ (n $=240)$ were females and 39\% $(\mathrm{n}=154)$ were males. In addition, $70 \%$ fell in the age category 18 years to 25 years and $17 \%(n=67)$ and $13 \%(n=50)$ fell in the age categories 26 years to 35 years and 36 years to 45 years respectively.

\section{University Students' Perceptions of Entrepreneurial Characteristics}

Firstly, in order to explore the key dimensions of entrepreneurship perceived by university students, the twenty nine (29) items were submitted into an exploratory factor analysis using Varimax rotation with the total sample $(n=394)$. As with other previous studies that have used an exploratory factor analysis to examine the dimensionality of concepts (Makgosa, 2006; Mgaya and Magembe 2007), to retain factors the following criteria were used: (i) eigen values $\geq 1$, (ii) items that loaded $\geq .30$ were retained and (iii) all items that loaded highly in more than one factors were deleted. Overall, eight (8) items loaded highly in more than one factor and were deleted. The eight deleted items are listed below: (1) An entrepreneur is someone who spots a new opportunity; (2) Entrepreneurship is about hardworking, (3) An entrepreneur is achievement oriented, (4) An entrepreneur is strategically aware and always customer focused, (5) A person who provides risk capital to start a new venture but did not provide initiative himself is an entrepreneur, (6) In order for you to become an entrepreneur, you have to invent the idea in the first place, (7) An entrepreneur contributes to the economic growth of the country and (8) In order for an entrepreneur to be successful there should be technological resource.

The final output based on the 21 items that were retained generated six factors that contributed $64.97 \%$ of the total variance explained. Based on the factor loadings, the six factors were labelled as (1) Right managerial skills (2) Taking risks (3) Economic role (4) Use of available resources optimally (5) Creativity and (6) Successful. A reliability analysis also demonstrated that the factors have achieved a high level of reliability with scores ranging from $\alpha=.50$ to $\alpha=.89$. The results of the exploratory factor analysis and reliability analysis are presented in Table 1. 


\section{Macrothink}

International Journal of Learning \& Development

ISSN 2164-4063

2012, Vol. 2, No. 3

Table 1: Key Characteristics of Entrepreneurship as Perceived by University Students

\begin{tabular}{|c|c|c|}
\hline & $\begin{array}{l}\text { Factor } \\
\text { Loadings }\end{array}$ & $\begin{array}{l}\% \text { of Variance } \\
\text { Explained }\end{array}$ \\
\hline $\begin{array}{l}\text { Factor 1: Entrepreneurship requires the right managerial } \\
\text { skills }\end{array}$ & $\alpha=.89$ & $27.98 \%$ \\
\hline An entrepreneur must have human relation skills. & .86 & \\
\hline An entrepreneur must have leadership skills. & .85 & \\
\hline An entrepreneur must have communication skills. & .77 & \\
\hline An entrepreneur must have negotiation skills. & .70 & \\
\hline Factor 2: Entrepreneurship involves taking risk & $\alpha=.70$ & $9.77 \%$ \\
\hline $\begin{array}{l}\text { Entrepreneurs are different from other people in that they } \\
\text { have different attitudes toward risk. }\end{array}$ & .78 & \\
\hline An entrepreneur is a risk taker. & .72 & \\
\hline $\begin{array}{l}\text { Being a successful entrepreneur has more to do with } \\
\text { visionary, a dreamer or charismatic. }\end{array}$ & .66 & \\
\hline $\begin{array}{l}\text { An entrepreneur is someone who shows initiative, } \\
\text { creativity, innovativeness, imagination and flexibility. }\end{array}$ & .57 & \\
\hline $\begin{array}{l}\text { Factor 3: Entrepreneurship plays an instrumental role in } \\
\text { the economy }\end{array}$ & $\alpha=.74$ & $8.69 \%$ \\
\hline The entrepreneur plays the role of employment creation. & .81 & \\
\hline $\begin{array}{l}\text { The entrepreneur plays the role of diversification of the } \\
\text { economy. }\end{array}$ & .78 & \\
\hline The entrepreneur plays the role of wealth creation. & .73 & \\
\hline $\begin{array}{l}\text { Factor 4: Entrepreneurship involves utilizing resources } \\
\text { optimally }\end{array}$ & $\alpha=.72$ & $6.67 \%$ \\
\hline $\begin{array}{l}\text { Entrepreneurship to be successful, the organisation resources } \\
\text { must be available }\end{array}$ & .73 & \\
\hline $\begin{array}{l}\text { Entrepreneurship to be successful, they must be intellectual } \\
\text { and human resource. }\end{array}$ & .82 & \\
\hline $\begin{array}{l}\text { Entrepreneurship to be successful, there should be } \\
\text { information resource. }\end{array}$ & .69 & \\
\hline Factor 5: Entrepreneurship involves creativity & $\alpha=.58$ & $6.09 \%$ \\
\hline Anyone who starts a new business is an entrepreneur. & .83 & \\
\hline $\begin{array}{l}\text { Entrepreneurship means owning and managing your own } \\
\text { business. }\end{array}$ & .79 & \\
\hline Factor 6: Entrepreneurship is about being successful & $\alpha=.50$ & $5.76 \%$ \\
\hline Entrepreneurship is being rich. & .81 & \\
\hline An entrepreneur is always successful. & .80 & \\
\hline
\end{tabular}

Secondly, descriptive statistics mainly means were used to assess the perceptions of university students about entrepreneurship on average. Based on the means presented in Table 2, it is clear that on average students strongly agree that entrepreneurship requires some skills including marketing, negotiation, problem solving, communication, human resource and 
leadership. The overall mean score of 4.27 was achieved. Additionally, students strongly agreed that on average entrepreneurs should take risks which achieved the second highest mean score of 4.11. The third highest score was achieved for the fact that entrepreneurs should play a significant role in economic development and wealth creation achieving a mean score of 4.02. The fourth highest score was achieved for the fact that entrepreneurs need to utilize available resources effectively (mean score $=3.98$ ). Students also agreed that entrepreneurs need to be creative, which is represented by a mean score of 3.59. However, students did not agree that entrepreneurship has anything to do with being successful signified by a relatively low mean score of 2.55 .

Table 2: Perceptions of University Students about Entrepreneurship

\begin{tabular}{|l|l|}
\hline Key Characteristics of Entrepreneurship & Mean(SD) \\
\hline Entrepreneurship requires the right managerial skills & $4.28(.60)$ \\
\hline Entrepreneurship involves taking risk & $4.11(.64)$ \\
\hline Entrepreneurs play a significant role in the economy & $4.02(.65)$ \\
\hline Entrepreneurship is about utilizing resources optimally & $3.98(.64)$ \\
\hline Entrepreneurship involves creativity & $3.59(.89)$ \\
\hline Entrepreneurship is about being successful & $2.55(.98)$ \\
\hline
\end{tabular}

Note: $1=$ strongly disagree; 5 = strongly agree

In order to add more insight into entrepreneurial behaviour, we also investigated whether gender and age affect students' perceptions of entrepreneurial characteristics. Analysis of Variance (ANOVA) and t-tests were used. The results of t-tests demonstrated that gender does not affect student's perceptions on any of the six characteristics of entrepreneurship identified in this study.

However, the ANOVA test indicated that age has a significant effect on the perceptions of students with regard to three characteristics including: Entrepreneurship requires the right managerial skill: $\mathrm{F}_{(2,394)}=2.44, \mathrm{p}<.10$; Entrepreneurship involves taking risks: $\mathrm{F}_{(2,394)}=$ 2.23, $\mathrm{p}<.005$ and Entrepreneurship is about being successful: $\mathrm{F}_{(2,394)}=10.99, \mathrm{p}<.001$. In order to test where the difference lies, t-tests were conducted as shown in Table 3. The results of t-tests indicate that students below the age of 25 years differ significantly from those who are aged between 26 years and 36 years. The group that fall in age category 18 years to 25 years seems to share the same perceptions about entrepreneurship involves the right managerial skills, risk taking and being successful with those who aged between 36 years and 45 years. Furthermore, there are some significant differences between those in the middle aged group (26 years to 35 years) and those who are older (36 years to 45 years) in terms of skills, risk and success of business 


\section{Macrothink}

International Journal of Learning \& Development

ISSN 2164-4063

2012, Vol. 2, No. 3

Table 3: Age differences in perceptions of entrepreneurship

\begin{tabular}{|c|c|c|c|c|c|c|c|c|c|}
\hline $\begin{array}{l}\text { Character } \\
\text {-stics }\end{array}$ & $\begin{array}{l}18-25 \\
\text { years } \\
n=277\end{array}$ & $\begin{array}{l}26-35 \\
\text { years } \\
n=67\end{array}$ & $\mathbf{t}$ & $\begin{array}{l}18-25 \\
\text { years } \\
n=277\end{array}$ & $\begin{array}{l}36-45 \\
\text { years } \\
n=50\end{array}$ & $\mathbf{t}$ & $\begin{array}{l}26-35 \\
\text { years } \\
n=67\end{array}$ & $\begin{array}{l}36-45 \\
\text { years } \\
n=50\end{array}$ & $\mathbf{t}$ \\
\hline Skills & $4.30(.58)$ & $4.13(.73)$ & $1.99 * *$ & $4.30(.58)$ & $4.35(.52)$ & .56 & $4.13(.73)$ & $4.35(.52)$ & $-1.76^{* *}$ \\
\hline Risk & $4.16(.63)$ & $3.88(.72)$ & $3.17 * * *$ & $4.16(.63)$ & $4.14(.50)$ & .25 & $3.88(.72)$ & $4.14(.50)$ & $-2.14 * * *$ \\
\hline Success & $2.46(.91)$ & $3.05(.95)$ & $-4.52 * * *$ & $2.46(.91)$ & $2.41(.91)$ & .32 & $3.05(.95)$ & $2.41(.91)$ & $3.68 * * *$ \\
\hline
\end{tabular}

Note: $* * * \mathrm{p}=.001$

$* * \mathrm{p}=.05$

$* \mathrm{p}=.10$

\section{Motivators and Challenges of Entrepreneurial Behaviour}

When students were asked about the possible motivators that could influence one to venture into entrepreneurship they mentioned several reasons as presented in Table 4. Among the five top motives that were mentioned by numerous students, three reasons are related to lack and creation of employment whereas the remaining two were concerned with the accumulation of wealth and the need to take advantage of available resources and financial support.

Table 4: Motivators for Venturing into Entrepreneurship

\begin{tabular}{|l|l|l|l|}
\hline Rank & Reasons & Number & Percentage \\
\hline 1 & Unemployment & 109 & $21.67 \%$ \\
\hline 2 & Self employment/own boss & 81 & $16.10 \%$ \\
\hline 3 & Create employment & 54 & $10.76 \%$ \\
\hline 4 & Wealth accumulation & 51 & $10.14 \%$ \\
\hline 5 & Availability of resources/funds support & 37 & $7.36 \%$ \\
\hline 6 & Diversify economy & 33 & $6.57 \%$ \\
\hline 7 & Favourable market & 32 & $6.36 \%$ \\
\hline 8 & Skill/Experience/Creativity & 30 & $5.96 \%$ \\
\hline 9 & Need Satisfaction & 26 & $5.17 \%$ \\
\hline 10 & Personal Desire for success & 13 & $2.58 \%$ \\
\hline
\end{tabular}

Note: Some respondents gave multiple reasons, while some did not respond (total responses $=503$ ). Other reasons that were mentioned achieved a percentage below $2.58 \%$ such as poor salary make a difference, role model aspiration, retirement, and poverty.

Another perspective that was captured in this study is about the challenges that are likely to be encountered in starting entrepreneurial ventures in Botswana. The most commonly cited challenge was lack of capital which was followed by insufficient market. The other cited challenges are presented in Table 5.

Table 5: Challenges to be encountered in starting Entrepreneurial Ventures in Botswana

\begin{tabular}{|c|l|l|l|}
\hline Rank & Problems & Number & Percentage \\
\hline 1 & Lack of capital/resources & 156 & $36.4 \%$ \\
\hline 2 & Insufficient market & 98 & $22.8 \%$ \\
\hline 3 & Small population & 30 & $7 \%$ \\
\hline 4 & Poor business practices & 30 & $7 \%$ \\
\hline 5 & Competition & 20 & $4.7 \%$ \\
\hline
\end{tabular}




\begin{tabular}{|l|l|l|l|}
\hline \hline 6 & Insufficient knowledge/information & 18 & $4.2 \%$ \\
\hline 7 & Lack of government support & 15 & $3.5 \%$ \\
\hline 8 & Government restrictions/policy & 12 & $2.8 \%$ \\
\hline
\end{tabular}

Note: Some respondents gave multiple reasons, while some did not respond (total responses $=429$ ). Other challenges that were mentioned achieved a percentage below $2.8 \%$ such as include: expensive products, risk, political and economic factors, lack of motivation, lack of recognition, technology, corruption, poor marketing strategy, over reliance on government, and lack of innovation.

\section{Discussion and Conclusion}

The term entrepreneurship has been defined in different ways by several authors (Littunen, 2000; Johnson, 2001). This study was an attempt to explore the key dimensions of entrepreneurship that are perceived by university students in Botswana. In this study six dimensions emerged and they include entrepreneurship is about having the right skills, taking risks, playing an important economic role, dealing with resource challenges, being successful and creative. These dimensions correspond to those identified by other previous studies reviewed in the literature (Johnson, 2001; Thompson, 1999). The descriptive statistics used to assess how strongly students agree or disagree with the perceived dimensions of entrepreneurship show that generally students did not associate entrepreneurship with success as they scored the lowest means in the dimension. Consistent with past studies (Gruel and Atman, 2006; Henderson and Robertson, 1999; Postage et al., 2003) students perceived the right managerial skills, risk taking propensity, creativity, utilization of resources and the economic role as very critical. Additionally, a comparative analysis demonstrated that the students' perceptions did not differ in terms of gender. However, age seems to affect student's perceptions on the right managerial skills, risk taking and entrepreneurial success.

Findings relating to students perceptions of key characteristics of entrepreneurs contribute to the body of knowledge on entrepreneurship in Botswana. From the entrepreneurship education standpoint, clearly it shows that the content of entrepreneurship courses that are offered within the business curriculum in the Faculty of Business offer students the relevant foundation with respect to venturing into entrepreneurship. Therefore, tertiary institutions need to continue with their work of educating students on entrepreneurship. Interestingly, students identified several challenges that are likely to hinder them from venturing into entrepreneurship. This demonstrates that there is a need for creating awareness of sources of funding, training programmes and government policies that are aimed at stimulating entrepreneurial activities in Botswana. Additionally, those who are responsible for developing entrepreneurship programmes or policies need to consider the students' perceptions of entrepreneurship.

However, the current study's findings need to be interpreted in light of its limitations. For instance, no effort was made to investigate whether students are likely to start businesses. This is because students' perceptions of entrepreneurship could differ on the basis of their level of commitment towards starting a business. Future research could examine entrepreneurial behaviour from the perspectives of young entrepreneurs (those who have ventured into entrepreneurship) and students in other disciplines rather than just focusing on students who are pursuing the business degree. 


\section{References}

Bonu, N. S. (1999). Botswana: The impact of Public Policy on Entrepreneurship Development in African Entrepreneurship and Small Business Development, edited by Kinuda-Rutashobya, L and Olomi, D. R. Dar es Salaam: DUP LTD, 85-102.

Botswana Review of Commerce and Industry (2007-2008) $27^{\text {th }}$ edition, Bandit Directories, (PTY) LTD.

Collins, L.A., Smith A.J., and Hannon, P.D. (2006). Discovering entrepreneurship. An exploration of a tripartite approach to developing entrepreneurial capabilities. Journal of European industrial Training, 30(3): 188-205.

Day, J., Reynolds, P. and Lancaster, G. (2006).Entrepreneurship and the small to medium-sized enterprise. A divergent/convergent paradox in thinking patterns between advisers and SMEs owner-managers. Management Decision, 44(5): 581-597.

Fontela, E, Guzman, J, Perez, M and Javier, F. (2006). The art of entrepreneurship foresight. Journal of Foresight, 8(6): 3-13.

Galloway L., Kelly S, and Keogh W. (2006). Identifying Entrepreneurial Potential in students, National Council for Entrepreneurship, NCGE Working Paper Series, www.ncge.org.uk/research.php: Date accessed: 15 January 2010.

Gurol, Y. and Atsan N. (2006). Entrepreneurial characteristics amongst university students; some insights for entrepreneurship education and training in Turkey", Journal of Education and Training, 48 (1):25-38

Henderson, R. and Robertson, M. (1999). Who wants to an entrepreneur? Young adult attitudes to entrepreneurship as a career, Education and Training, 41(5): 236-245.

Henry, C. Hill, F., and Leitch, C. (2005). Entrepreneurship education and training. Can entrepreneurship be taught part 1.Journal of Education and Training, 47(2): 98-111.

Johnson, D. (2001). What is innovation and entrepreneurship? Lessons for larger organisations. Journal of Industrial and Commercial Training, 33 (4): 135-140.

Littunen, H. (2000). Entrepreneurial personality. Journal of Entrepreneurial Behaviour and Research, 6(6): 295-310.

Makgosa, R. (2006). A Test of Measure Equivalence of Conflict resolution Strategies Used in Joint Purchase Decisions. Botswana Journal of Business, 2(1): 19-45.

Mambula, C.J. and Sawyer, F.E. (2004). Art of Entrepreneurial creativity for business growth and Survival in a constrained economy. Journal of International of Social Economics, 31(1/2): 30-55.

Mgaya, K.V and Magembe, B.A (2007). Attitudes of University students towards entrepreneurship, World Review of entrepreneurship, Management and Sustainable Development, 3(2): 192-206.

Pretorius, M, Nieman, G, and Vuuren, J.V. (2005).Critical evaluation of two models for entrepreneurship education. Journal of International Education Management, 19(5): 413-427.

Postigo K. S, Iacobucci D. and Tamborini M. F. (2003). Undergraduate Students as Source of Potential Entrepreneurs: A Comparative Study between Italy and Argentina, paper presented at the $13^{\text {th }}$ Global IntEnt, September, 8-10, France. 
Ratashobya, L. K (1999). African Entrepreneurship and Small Business Development: A Conceptual Framework in African Entrepreneurship and Small Business Development edited by Kinuda-Rutashobya, L and Olomi, D. R. Dar es Salaam: DUP LTD, 19-52.

Republic of Botswana., National Development Plan 9 2003/2008. Ministry of Finance and Development Planning, March 2003.

Robertson, M., Collins, A., Medeira, N., and Slater, J. (2003). Barriers to start-up and their effect on aspirant entrepreneurs, Education and Training, 45(6): 308-316.

Ronan, N.J., Chinyoka S.V., Iwisi D., and Moeti N (1997). Fostering Entrepreneurial Skills in Botswana, Journal of Business, July/December, 1(2), 31-45.

Segal, G., Borgia, D., and Schoenfeld, J., (2005).The motivation to become an entrepreneur. International Journal of Entrepreneurial Behaviour and Research, 11 (1): 42-57.

Themba, G., Chamme, M., Phambuka, C.A., and Makgosa, R. (1999). Impact of Macro-Environmental Factors on Entrepreneurship Development in Developing countries in African Entrepreneurship and Small Business Development, edited by Kinuda-Rutashobya, L and Olomi, D. R. Dar es Salaam: DUP LTD, 103-119.

Thompson, J. L. (1999). The World of Entrepreneur-a New Perspective, Journal of Workplace Learning, 11(6), 209-224.

Thurik, R. and Wennekers, S. (2004). Entrepreneurship, Small business and economic growth. Journal of Small Business and Enterprise Development, 11(1): 140-149.

Timmons, J. A. (1994). New Venture Creation-Entrepreneurship for the 12st Century. Irwin, McGraw-Hill. New York. NY. 